\title{
Consistent individual differences in the foraging behaviour of forest tent caterpillars (Malacosoma disstria)
}

\author{
L. Nemiroff and E. Despland
}

\begin{abstract}
Outbreaking insects are often considered identical units despite recent work in behavioural ecology that shows repeatable differences can exist between individuals and can have important implications for individual fitness and population processes. However, although entomologists have neglected the hypothesis that differences between individuals can play an important role in the ecology of a species, it is not new. Wellington (1957. Can. J. Zool. 35: 293-323) suggested that consistent individual differences in behaviour may play a role in the population dynamics of Malacosoma (Hübner, 1820) species (Lepidoptera: Lasiocampidae). We used a novel approach to determine if individual larval Malacosoma disstria Hübner, 1820 exhibit distinct and repeatable behavioural traits. Second-instar caterpillars were placed on individual arenas for $1 \mathrm{~h}$ on 4 consecutive days, and the proportion of time spent walking, searching, quiescent, and eating was documented. Active and sluggish behavioural types were distinguished and stable differences in individual activity were observed. Activity was positively correlated with growth during the 4 days of the experiment, but no significant relationship was detected between behaviour during the experiment and overall larval performance in the laboratory setting. These findings demonstrate consistent variation in the foraging behaviour of forest tent caterpillars and lay the basis for further investigatison of its role in colony function and population dynamics.
\end{abstract}

Résumé : Les insectes épidémiques sont souvent considérés comme des unités identiques, même si des travaux récents d'écologie comportementale montrent que des différences persistantes peuvent exister entre les individus et avoir des conséquences importantes sur la fitness individuelle et les processus démographiques. Bien que les entomologistes aient négligée l'hypothèse selon laquelle les différences entre les individus peuvent jouer un rôle important dans l'écologie d'une espèce, celle-ci n'est pas nouvelle. Wellington (1957. Can. J. Zool. 35: 293-323) avait suggéré que des différences persistantes de comportement pouvaient jouer un rôle dans la dynamique de population des espèces de Malacosoma (Hübner, 1820) (Lepidoptera : Lasiocampidae). Nous utilisons une méthodologie inédite afin de déterminer si les larves individuelles de Malacosoma disstria Hübner, 1820 possèdent des caractéristiques comportementales distinctes et persistantes. Nous avons placé des chenilles de deuxième stade dans des arènes individuelles pour $1 \mathrm{~h}$ pendant 4 jours consécutifs et nous avons noté la proportion du temps passé à la marche, la recherche, le repos et l'alimentation. Il est possible de distinguer des types comportementaux actifs et léthargiques; ces différences d'activité individuelle globale sont stables. Il y a une corrélation positive entre l'activité et la croissance durant les 4 jours de l'expérience; en revanche, il n'y a aucune corrélation significative entre le comportement durant l'expérience et la performance globale des larves dans les conditions de laboratoire. Nos résultats montrent une variation persistante dans le comportement de recherche de nourriture chez la livrée des forêts; il s'agit là d'une base pour des recherches futures sur le rôle de cette variation dans le fonctionnement des colonies et la dynamique des populations.

[Traduit par la Rédaction]

\section{Introduction}

The concept of consistent intraspecific differences in behaviour has become a central focus in behavioural ecology over the last several decades (Sih and Watters 2005). Consistent behavioural traits have been demonstrated in animals ranging from insects and spiders to fish, birds, and mam-

Received 26 October 2006. Accepted 13 July 2007. Published on the NRC Research Press Web site at cjz.nrc.ca on 20 November 2007.

L. Nemiroff ${ }^{\mathbf{1}}$ and E. Despland. ${ }^{2}$ Department of Biology,

Concordia University, 7141 Sherbrooke Street West, Montreal, QC H4B 1R6, Canada.

${ }^{1}$ Present address: Department of Biology, Dalhousie University, 1355 Oxford Street, Halifax, NS B3H 4J1, Canada.

${ }^{2}$ Corresponding author (e-mail: Despland@alcor.concordia.ca). mals, and include such differences as bold vs. shy, exploratory vs. neophobic, and active vs. inactive types (reviewed in Wilson et al. 1994; Sih et al. 2004). Such individual differences in behavioural traits have been shown to be moderately heritable and essentially stable over the entire life of the individual (van Oers et al. 2005).

Differences between active and less active foraging types have been documented in Drosophila melanogaster Meigen, 1830 and in Caenorhabditis elegans (Maupas, 1900), and in both cases have been shown to depend on expression of a single gene (Sokolowski 2001; de Bono 2003). In D. melanogaster, this variation in foraging behavior influences a larva's ability to exploit food resources (Sokolowski 1985), leading to differences in larval development and growth (Bakker 1961; Robertson 1963; Ohnishi 1979), and hence in fitness.

However, the effect of a behavioural trait on fitness is 
often dependent on the environment (Sih and Watters 2005). Namely, selection that favours a particular behavioural trait (e.g., more active) in one situation, such as during poor food conditions, may cause inappropriate behaviour in other environmental conditions, such as during high predation (Sih et al. 2004). For social animals, the fitness of a behavioural trait appears to depend on both the external environment and the mix of behavioural traits within the group. The frequency of different behavioural traits in a social group may influence the overall behaviour of the group (Sih and Watters 2005). An extreme example of this behavioural specialization within groups is seen in the eusocial Hymenoptera, where the proper functioning of the colony depends on the frequency distribution of behavioural types (Beshers and Fewell 2001).

Despite growing evidence that the presence of different behavioural types can significantly affect group dynamics and population processes (DeAngelis and Mooij 2005), entomologists still tend to consider conspecific insects to be identical units. The main exception is locusts, where a dramatic change between two individual types, solitarious and gregarious, is known to be the basis for outbreaks (Despland 2004).

However, the idea that different individual types might play an important role in Canadian forest insect outbreaks was first proposed many years ago (Wellington 1977). Distinct behavioural types were suggested to play a role in the population dynamics of tent caterpillars (species of Malacosoma Hübner, 1820), an economically important outbreaking Lepidoptera species (Wellington 1957). Tent caterpillar eggs are deposited in a continuous band around a twig. The larvae hatch within hours of each other and construct a silk tent or silk bivouac, from which they go on synchronized bouts of collective foraging (Fitzgerald 1995). Foraging is directed by silk trails marked with pheromones, and foraging success is highly dependent on trail-following during the first instars (Fitzgerald and Webster 1993). Wellington (1957) provided some of the first indications of behavioural types in Malacosoma species. By placing newly eclosed larval Malacosoma californicum pluviale (Dyar, 1893) on paper in rows parallel to a $30 \mathrm{~W}$ fluorescent bulb and observing their progression towards the light for $10 \mathrm{~min}$ over a period of 3 consecutive days, he determined that individuals displayed major differences in behaviour. They were classified into type I individuals, capable of independent and directed movement towards a light source, and subgroups of type II larvae, ranging from individuals with active but undirected movement to sluggish individuals that rely heavily on silk trails and stimulation from more active larvae. The differences were believed to be stable over time and were traced back to the individual's place in the original egg band, where active larvae hatched from the first-laid eggs and sluggish individuals from among the last-laid eggs (Wellington 1965). The proportion of different behavioural types was shown to vary between egg bands and to influence the functioning and performance of the colony (Wellington 1960). Fluctuation in the frequencies of the different phenotypes was predicted to contribute to outbreak dynamics (Iwao and Wellington 1970).

Over the years, several researchers have attempted to reproduce Wellington's (1957) experiments with limited success. Greenblatt and Witter (1976) replicated Wellington's
(1957) technique using forest tent caterpillars, Malacosoma disstria Hübner, 1820, with minor variations. They categorized newly eclosed caterpillars that travelled $>3 \mathrm{~cm}$ towards a light source during $20 \mathrm{~min}$ of testing as active, while the others were deemed sluggish. Their results show that the larvae did not respond to the light at random. Instead, some individuals showed a tendency to respond to the light test, while other larvae tended not to. They also observed that the number of active larvae were different between egg masses. Contrary to Wellington's (1957) results, however, testing over 3 consecutive days during the first instar revealed that few of the larvae remained active for more than one test period and that the majority of the individuals exhibited sluggish behaviour. In this study, caterpillars were kept isolated and unfed during the first days of their lives. Before the third instar, tent caterpillars are highly dependent on their conspecifics and have been shown to grow more slowly when isolated in the laboratory, even in optimal conditions (Robison 1993), and hence this long period of starvation and isolation might lead to an overexpression of sluggish behaviour over the length of the 3-day trials by Greenblatt and Witter (1976). Certainly the very high proportion of sluggish caterpillars observed indicates a problem, either with the quality of the caterpillars or with the conditions in which they were maintained.

Edgerly and Fitzgerald (1982) then investigated intracolony variability in activity levels of the eastern tent caterpillar, Malacosoma americanum (Fabricius, 1793). They further modified Wellington's (1957) apparatus by using narrow strips of graduated paper that more closely mimicked branches, and $5 \mathrm{~min}$ trials were repeated for isolated individuals over the first three instars. Their results indicated that the activity ranks of individuals were not consistent between test periods. Once again, maintaining caterpillars in isolation before the third instar seriously prejudices their growth and development (and likely their behaviour). Moreover, $5 \mathrm{~min}$ trials might not be long enough for an adequate measure of an individual's behaviour and may easily allow resting active caterpillars to be confused with sluggish larvae.

Finally, Myers (1978) attempted to construct active and sluggish groups of M. c. pluviale by combining the first-laid halves of two egg bands and the last two halves of the same egg bands, respectively, and was unable to reproduce Wellington's (1965) findings. Individuals from both groups were equally active and first-laid individuals did not display increased foraging success. However, the authors admit that it is not certain that the two halves of the egg band really represented the first-laid and last-laid eggs (Myers 1978) - if this is not the case, there is no reason to expect differences between the two parts of the egg mass. In addition, this study did not test whether individual differences persist over time.

It is therefore still not clear whether tent caterpillars exhibit consistent differences in foraging behaviour. In light of recent research on behavioural types (Sih et al. 2004) and on individual differences and emergent group properties (DeAngelis and Mooij 2005), it seems likely that such differences, if they exist, play an important role in the organization of tent caterpillar colonies, and possibly in the generation of outbreaks - whether or not in the way envis- 
aged by Wellington in 1965. The purpose of this study is to start to address this question from the bottom-up, by testing for the presence or absence of consistent behavioural traits in the forest tent caterpillar using a novel technique. Activity levels, defined in this case by the amount of time each individual spent walking, searching, quiescent, eating, and the latency to reach the food source were used to indicate behavioural type. Based on Wellington's (1957) work, we predicted (1) that individual activity trends would remain stable over the several days of observation, (2) that two behavioural categories (active and sluggish) would be distinguishable, (3) that the proportion of behavioural types would vary among egg bands, and (4) that there would be a relationship between behavioural type and performance during larval development.

\section{Materials and methods}

\section{Subjects}

Forest tent caterpillars were reared in the laboratory from eggs obtained from the Canadian Forest Service Great Lakes Forestry Centre in Sault Ste. Marie, Ontario. The eggs were from laboratory-reared cultures, regularly supplemented by moths caught from moderately dense populations (not outbreaking). A total of six egg bands were used. Each egg band was soaked in $6 \%$ sodium hypochlorite for $1 \mathrm{~min}$ and $30 \mathrm{~s}$, rinsed with cool water for $5 \mathrm{~min}$, washed in $0.06 \%$ sodium hypochlorite, and finally, air dried (Grisdale 1985). It was then kept in a growth chamber at $22{ }^{\circ} \mathrm{C}$ on a $16 \mathrm{~h}$ light : $8 \mathrm{~h}$ dark photoperiod with $70 \% \mathrm{RH}$. The caterpillars were fed ad libitum on a standard, balanced artificial diet (Addy 1969).

To test individual behavioural differences, 12-15 forest tent caterpillars were chosen from each egg band several hours after molting to their second instar. Caterpillars were selected randomly from among several dozen that had molted. They were then marked with dots of nontoxic, washable paint on the abdominal setae. Patterns of paint allowed for identification of individuals during the trials. A total of 85 caterpillars were used.

\section{Behaviour tests}

Behavioural trials were $1 \mathrm{~h}$ long per day and were repeated at $24 \mathrm{~h}$ intervals for 4 consecutive days for each egg band. As often as possible, the time of day was the same between trials. Testing started on the 2nd day of the caterpillars' molt to the second instar, which optimized testing time while ensuring that none of the caterpillars molted into their third instar before the end of the trials. All individuals from each egg band were tested at the same time, with egg bands being prepared sequentially. Trials lasted from September to December 2005.

At the beginning of a trial, each marked individual was placed at one end of an $11.3 \mathrm{~cm} \times 0.6 \mathrm{~cm}$ wood arena, with a small square of fresh food placed at the opposite end. The test area was arranged so that all arenas received comparable amounts of light, and the placement of each caterpillar among arena positions was randomized every day. Caterpillars were separated from the food by a $1 \mathrm{~cm} \times$ $1 \mathrm{~cm} \times 1 \mathrm{~cm}$ barrier. Both the barrier and the sides of the arena were covered in fluon (AG Fluoropolymer) to restrict the larva to the observation area. Arenas were replaced after each trial to ensure that pheromone trails were not present. These arenas did not include a long-distance cue to direct movement, since caterpillars cannot detect artificial food odour (Schoonhoven 1987).

To control for hunger effects, caterpillars were reared with ad libitum food and were food deprived for $1 \mathrm{~h}$ prior to testing to reduce the effects of postprandial quiescence, after which the barriers were removed and observation commenced. During each trial, interval scans were performed every $45 \mathrm{~s}$ and each individual's activities were recorded into the Pocket Noldus Observer version 2.0.19 (Noldus Information Technology Inc. 2003; see Table 1).

Each day after the hour long observation, the caterpillars were removed from the arenas, weighed, and then placed back into their colonies in growth chambers under the same conditions as described above. After the 4th day of testing, the experimental caterpillars were weighed, isolated, and reared to maturity in individual petri dishes lined with a moistened paper towel covered with wax paper, and provided with a constant supply of fresh food. Pupae were weighed and sexed $48 \mathrm{~h}$ after the appearance of a coccoon, when metamorphosis was complete.

\section{Statistical analysis}

To determine if individuals exhibited consistent behavioural tendencies (prediction 1) over the 4 days of observations, repeatability analysis with associated one-way ANOVAs (Lessells and Boag 1987) was performed on the proportion of time spent walking, searching, quiescent, and eating food, as well as on latency to reach food. Repeatability represents the proportion of total variation in a trait that can be explained by differences between individuals. A repeatability $(r)$ value of 0 indicates that all variance is within an individual over repeated measurements, whereas a $r$ value of 1 indicates that repeated measurements of that individual give identical results (Sokal and Rohlf 1981; Lessells and Boag 1987). A full $24 \mathrm{~h}$ between observation periods ensured that the behaviour during each trial did not depend on what had occurred in the previous observation period. A Spearman's nonparametric correlation between behaviours on the 4 different days was also performed.

A $K$-means cluster analysis was then performed to determine if the caterpillars could be divided into two main types (prediction 2): active and sluggish. $K$-means clustering divides a set of values into a selected number of groups by maximizing between-group variation relative to within-group variation. It iterates through the data until cases are successfully clustered (Everitt et al. 2001). A repeated-measures MANOVA (MANOVAR) was then performed to examine behavioural differences between clusters and between the 4 days of the study. Proportion of time spent walking, searching, quiescent, eating, and latency to reach food were the dependent variables, day number was the within-subject factor, and cluster number was the between-subject factor.

Chi-square tests compared the frequency distribution of the two types between egg bands and between the sexes (prediction 3). MANOVAR tested for differences between egg bands and between the sexes in the raw behavioural data.

Bivariate correlations with pairwise deletion were performed to test the relationship between behaviour during the observation period and performance (prediction 4). The var- 
Table 1. Descriptions of the five mutually exclusive, easily recognizable activities noted for each forest tent caterpillar (Malacosoma disstria), using the Pocket Noldus Observer version 2.0.19 (Noldus Information Technology Inc. 2003).

\begin{tabular}{|c|c|}
\hline Activity & Description \\
\hline Walking & $\begin{array}{l}\text { The individual exhibits directed locomotion and moves at a consistent rate of at } \\
\text { least } 1 \text { body length / s }\end{array}$ \\
\hline Searching & $\begin{array}{l}\text { The individual's abdominal prolegs are stationary, while the anterior section of the } \\
\text { body is raised from the ground and moves in all directions. Caterpillars search } \\
\text { for trail pheromones with sensilla on the maxillary palps. The caterpillar moves } \\
\text { its head in the direction of the strongest signal to locate a trail (Fitzgerald and } \\
\text { Webster 1993) }\end{array}$ \\
\hline Quiescent & The individual is motionless \\
\hline Reaching food & $\begin{array}{l}\text { The individual's head makes contact with the food. This was recorded to calculate } \\
\text { latency to reach food, which is indicative of foraging success. Individuals that } \\
\text { did not reach the food within the } 1 \mathrm{~h} \text { trial period were given a latency to reach } \\
\text { food of } 3600 \mathrm{~s}\end{array}$ \\
\hline Eating food & $\begin{array}{l}\text { The individual's head remains in contact with the food, and back and forth } \\
\text { movement of the mandibles is visible }\end{array}$ \\
\hline
\end{tabular}

Table 2. Spearman's nonparametric correlation coefficients $(\rho)$ between the 4 different days of the trial for each recorded behaviour of forest tent caterpillars.

\begin{tabular}{|c|c|c|c|}
\hline & Day 2 & Day 3 & Day 4 \\
\hline \multicolumn{4}{|c|}{ Latency } \\
\hline Day 1 & $0.27 *$ & $0.25^{*}$ & 0.21 \\
\hline Day 2 & 1 & $0.33 * *$ & 0.20 \\
\hline Day 3 & & 1 & $0.30 * *$ \\
\hline Day 4 & & & 1 \\
\hline \multicolumn{4}{|c|}{ Quiescent } \\
\hline Day 1 & $0.27 *$ & $0.38 * *$ & 0.10 \\
\hline Day 2 & 1 & $0.37 * *$ & 0.15 \\
\hline Day 3 & & 1 & $0.42 * * *$ \\
\hline Day 4 & & & 1 \\
\hline \multicolumn{4}{|c|}{ Walking } \\
\hline Day 1 & 0.19 & $0.5 * * *$ & $0.24 *$ \\
\hline Day 2 & 1 & $0.30 * *$ & -0.04 \\
\hline Day 3 & & 1 & $0.36^{* * *}$ \\
\hline Day 4 & & & 1 \\
\hline \multicolumn{4}{|c|}{ Searching } \\
\hline Day 1 & $0.49 * * *$ & $0.53 * * *$ & 0.07 \\
\hline Day 2 & 1 & $0.48 * * *$ & 0.20 \\
\hline Day 3 & & 1 & $0.21 *$ \\
\hline Day 4 & & & 1 \\
\hline \multicolumn{4}{|l|}{ Eating } \\
\hline Day 1 & 0.15 & $0.32 * *$ & -0.07 \\
\hline Day 2 & 1 & 0.06 & 0.08 \\
\hline Day 3 & & 1 & $0.21 *$ \\
\hline Day 4 & & & 1 \\
\hline
\end{tabular}

Note: *, $P<0.05$; **, $P<0.01$; ***, $P<0.001$.

iables used were as follows: growth rate $(\mathrm{mg})$ over the 4 days of observation, pupal mass (mg), total larval development time (days), and mean proportion of time spent walking, searching, quiescent, and eating food, as well as the latency to reach food. A MANOVA was then performed on growth rate, pupal mass, and total larval development time, with sex and cluster number as independent variables. A Pearson $\chi^{2}$ test compared the frequency distribution of cat-
Table 3. $K$-means cluster analysis.

\begin{tabular}{|c|c|c|c|c|}
\hline \multirow[b]{2}{*}{ Activity } & \multicolumn{2}{|c|}{$\begin{array}{l}\text { Cluster centres } \\
\text { (\% time) }\end{array}$} & \multirow[b]{2}{*}{$F$} & \multirow[b]{2}{*}{$P$} \\
\hline & Cluster 1 & Cluster 2 & & \\
\hline Walking & 19.21 & 21.51 & 1.797 & 0.184 \\
\hline Searching & 52.79 & 53.14 & 0.017 & 0.898 \\
\hline Quiescent & 21.95 & 16.00 & 3.886 & 0.052 \\
\hline Eating food & 1.83 & 5.09 & 41.428 & 0.000 \\
\hline $\begin{array}{l}\text { Latency to reach } \\
\text { food }\end{array}$ & $2926.51^{a}$ & $1346.48^{a}$ & 221.559 & 0.000 \\
\hline$N$ & 52 & 33 & & \\
\hline Behavioural type & Sluggish & Active & & \\
\hline
\end{tabular}

Note: The first two columns show the two cluster centres for each variable, which are used to assign each individual to the closest cluster. The $F$ values and associated $P$ values reflect each variable's contribution to the clustering.

${ }^{a}$ Measured in seconds.

erpillar survivorship between the clusters. All statistical analyses were performed in SPSS ${ }^{\circledR}$ version 12.0.1 (SPSS Inc. 2003).

\section{Results}

\section{Prediction 1: Persistence of stable interindividual differences}

The caterpillars displayed overall interindividual differences in activity over the 4 trial days (MANOVA, overall analysis, $\left.F_{[84,239]}=2.94, P<0.001\right)$. Repeatability analysis ( $r$ ) demonstrated stable consistent differences between caterpillars in the amount of time spent walking (ANOVA, $F_{[84,239]}=1.66, P=0.002, r=0.22$ ), searching (ANOVA, $F_{[84,239]}=2.39, P<0.001, r=0.57$ ), quiescent (ANOVA, $\left.F_{[84,239]}=2.15, P<0.001, r=0.40\right)$, and in the latency to reach the food (ANOVA, $F_{[84,239]}=2.38, P<0.001, r=$ 0.58) during the experiment. Only the proportion of time spent eating food did not show greater between-individual than within-individual differences (ANOVA, $F_{[84,239]}=$ 1.24, $P=0.109, r=0.07)$. A Spearman's correlation determined that the recorded activities were significantly corre- 
Fig. 1. Average activity budgets for the two forest tent caterpillar (Malacosoma disstria) clusters. The $y$ axis illustrates the mean ( \pm 1 SE) proportion of assay time caterpillars spent displaying each activity during each of the observation days.

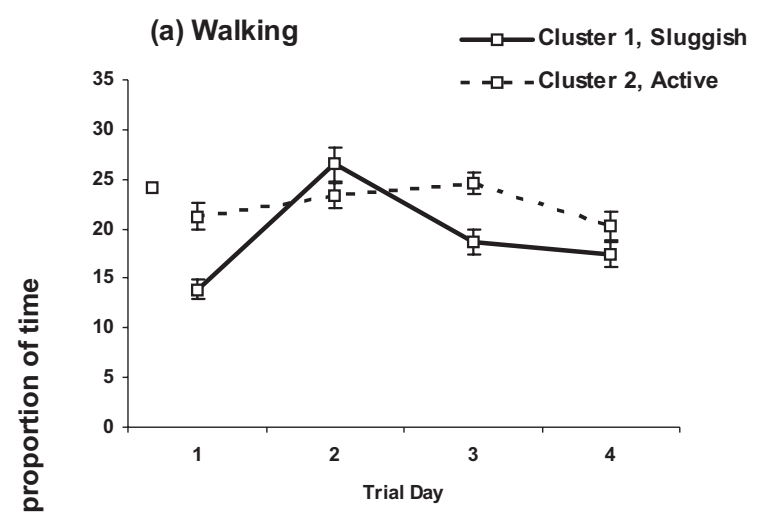

(b) Quiescent
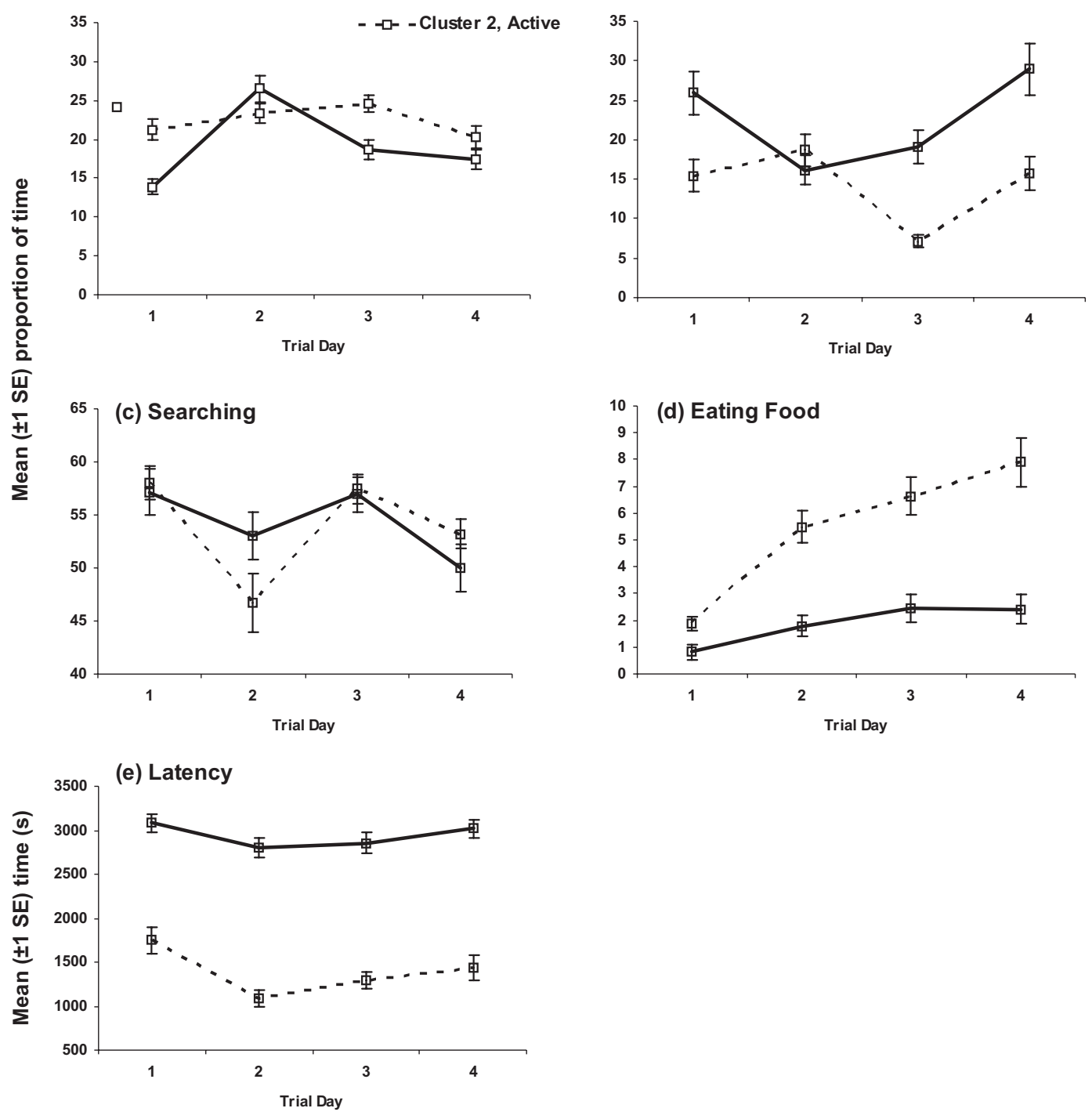

lated within individuals over the 4 trial days, further indicating consistency of behaviour (Table 2).

\section{Prediction 2: Clustering into active and sluggish types}

The $K$-means cluster analysis revealed that the larvae could then be divided into two main foraging types, with the first group spending more time quiescent and with a higher latency to reach the food source and the second group displaying more walking. The final cluster centres are summarized in Table 3. The repeated-measures MANOVA results, which compared individual activity budgets per day between the two clusters, are illustrated in Fig. 1. Activity budgets differed between caterpillars from the two clusters (MANOVAR, overall analysis, $F_{[5,61]}=39.45, P<0.001$ ). Day number was significant $\left(F_{[5,193]}=6.20, P<0.001\right)$, as was the interaction between day and cluster $\left(F_{[5,193]}=3.18\right.$, $P=0.009)$. The sluggish group showed reduced activity on the 1st and 4th days of testing, reflecting the lethargy induced by previous and upcoming molts, whereas the active group showed less difference in behaviour between the

4 days of testing (see Fig. 1). The proportion of time spent eating food increased predictably over the length of the 4 day trial for both active and sluggish individuals as the caterpillars grew larger, although active caterpillars consistently ate more. The single variable showing the clearest difference between the two clusters was latency to reach food. The average latency to reach the food over the four trials was $<35$ min for all active larvae and $>36$ min for all sluggish larvae (for frequency distributions of individual trial latencies see Fig. 2). These findings suggest that the clusters do indeed represent significant differences in foraging behaviour.

\section{Prediction 3: Distribution of phenotypes within egg bands}

When cluster number was cross-tabulated with egg-band number, a Pearson $\chi^{2}$ test showed no significant differences in the proportion of sluggish and active individuals per band $\left(\chi_{[5]}^{2}=8.12, P=0.15\right)$. Four of the six families had a nearly even distribution of active and sluggish phenotypes among the caterpillars tested, while two of the egg bands were pre- 
Fig. 2. Frequency distributions of the latency to reach the food source for all trials $(n=340)$. The final bin includes those caterpillars that never reached the food within the assay time.

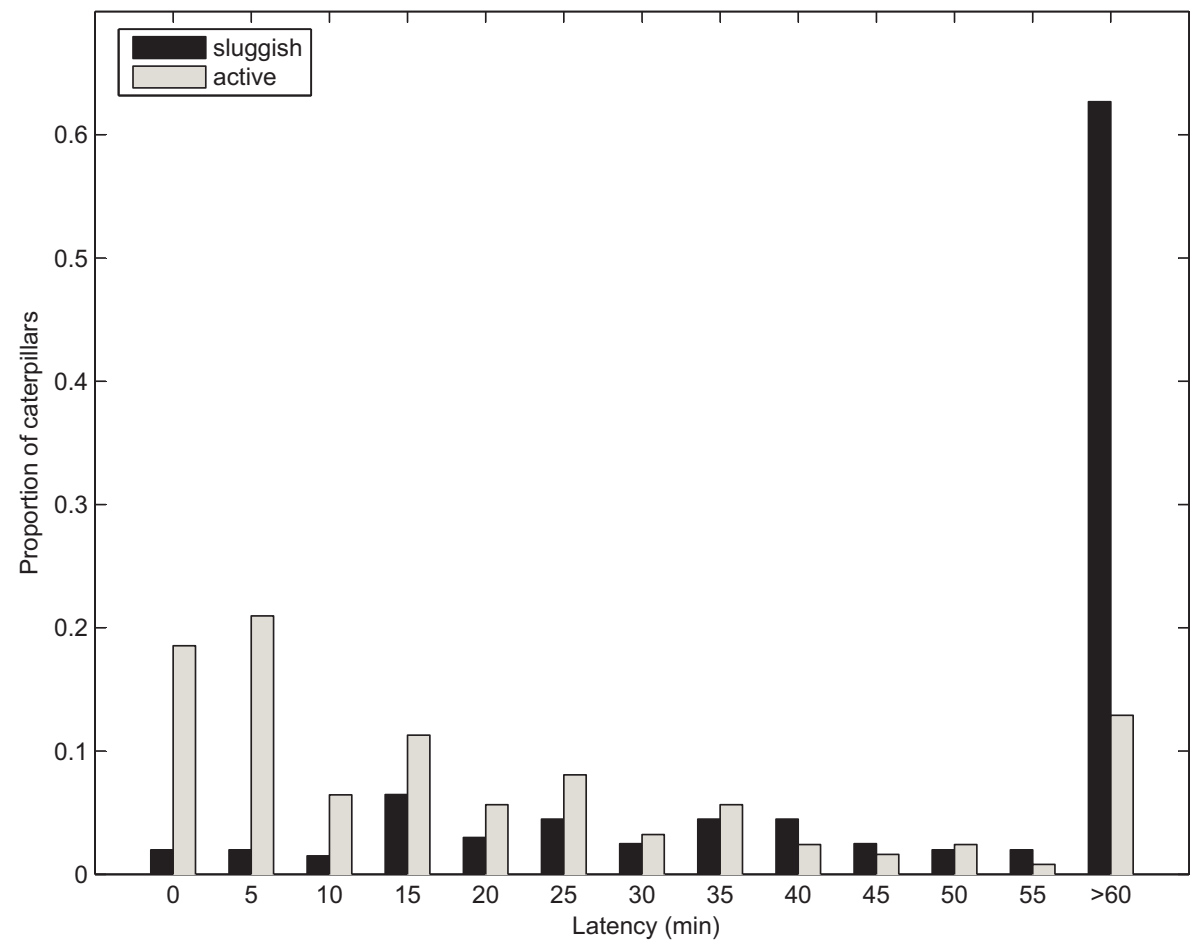

dominantly sluggish (see Fig. 3). When cluster number was cross-tabulated with sex, a Pearson $\chi^{2}$ test showed no significant difference in the proportion of males and females in the active and sluggish clusters $\left(\chi_{[1]}^{2}=1.354, P=0.245\right)-$ sluggish cluster: $38 \%$ male, $62 \%$ female; active cluster: $55 \%$ males, $45 \%$ females.

Repeated-measures MANOVA on the raw data showed significant differences in behaviour between egg masses $\left(F_{[5,18]}=12.2, P<0.001\right)$, but none between the sexes $\left(F_{[5,15]}=0.88, P=0.51\right)$.

\section{Prediction 4: Relationship with performance}

Growth rate $(\mathrm{mg})$ over the 4 days of observation was negatively correlated with time spent quiescent (see Table 4). However, bivariate correlations showed no relationships between behaviour during the experiment and performance indices measured at the end of larval development (see Table 4).

MANOVA indicated that, although sex predictably affected pupal mass $\left(F_{[1,80]}=61, P<0.001\right)$, cluster number did not influence pupal mass $\left(F_{[1,80]}=3.26, P=0.079\right)$ or larval development time $\left(F_{[1,80]}=0.001, P=0.978\right)$, which supports the results from the raw data. Out of 85 larvae, 42 survived to pupation and 34 survived to eclosion. A $\chi^{2}$ test indicated that cluster number did not affect survivorship $\left(\chi_{[1]}^{2}=0.569, P=0.451\right)$.

\section{Discussion}

These findings support predictions 1 and 2, showing that consistent behavioural differences exist between individual forest tent caterpillars and that these allow caterpillars to be classified into active and sluggish foraging types. Our findings show only weak evidence of differences in the fre- quency distribution of behavioural traits between egg bands (prediction 3). Finally, there was no clear indication of performance differences between the behavioural types (prediction 4). This is likely indicative of the influence of a laboratory setting, where the presence of readily available food and the lack of predation neutralized any potential fitness advantages or disadvantages of behavioural type. Clearly, a significant amount of research remains to be performed to examine these last two predictions, and some avenues for further study are discussed below.

Of all the behavioural variables tested, the latency to reach the food source displayed the clearest interindividual differences while maintaining a significant level of intraindividual stability during the 4 day trial periods. Second-instar forest tent caterpillars follow pheromone-laden silk trails to reach food (Fitzgerald and Webster 1993; Colasurdo and Despland 2005). As there were no trails provided on the arenas for the caterpillars to follow, decreased latency is indicative of increased exploration. Active individuals showed a much lower latency to reach a novel food source than sluggish larvae, indicating greater independence and exploration ability. Young forest tent caterpillars display a reluctance to advance over unmarked substrate (Despland and Hamzeh 2004; Colasurdo and Despland 2005) and this significantly decreases their performance in the absence of trails (Despland and Le Huu 2007). Our findings show that this reluctance is lower in active than in sluggish caterpillars, suggesting that these individuals might tend to initiate silk trails and act as group leaders. Observations of forest tent caterpillar colonies show that collective foraging is initiated by vanguard individuals that advance over unmarked territory and leave a trail for others to follow. The present study shows that some individuals consistently show greater mobi- 
Table 4. Bivariate correlations (pairwise deletion) between average behaviour during the 4 days of the test and performance.

\begin{tabular}{|c|c|c|c|c|c|c|}
\hline \multirow[b]{2}{*}{ Activity } & \multicolumn{2}{|l|}{ Growth rate } & \multicolumn{2}{|c|}{ Pupal weight (mg) } & \multicolumn{2}{|c|}{ Larval development (days) } \\
\hline & $\begin{array}{l}\text { Correlation } \\
\text { coefficient }\end{array}$ & $P$ & $\begin{array}{l}\text { Correlation } \\
\text { coefficient }\end{array}$ & $P$ & $\begin{array}{l}\text { Correlation } \\
\text { coefficient }\end{array}$ & $P$ \\
\hline Quiescent & -0.247 & $0.023 *$ & 0.167 & 0.291 & -0.168 & 0.289 \\
\hline Walking & 0.111 & 0.312 & -0.295 & 0.058 & -0.057 & 0.722 \\
\hline Searching & 0.145 & 0.186 & 0.242 & 0.122 & 0.178 & 0.259 \\
\hline Eating food & 0.175 & 0.110 & -0.137 & 0.388 & 0.191 & 0.225 \\
\hline Latency to reach food & -0.132 & 0.229 & 0.311 & $0.045^{*}$ & 0.053 & 0.740 \\
\hline
\end{tabular}

Note: $*, P<0.05$.

Fig. 3. Frequency distribution of the two behavioural types (active or sluggish) per egg band.

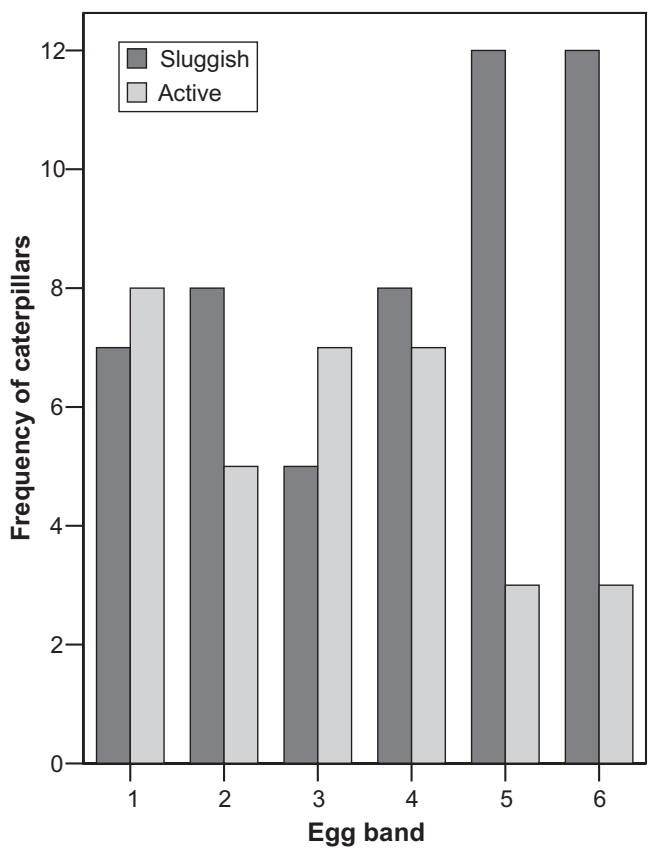

lity in the absence of trails compared with others. Our findings therefore suggest that the emergence of leaders and followers in a group does not only depend on individual state (e.g., hunger) but also composes a significant repeatable component. Indeed, certain individuals have been shown to consistently assume the lead more often in processions of other social caterpillars (Weinstein and Maelzer 1997; Underwood and Shapiro 1999; Fitzgerald 2003).

Previous researchers have speculated on the adaptive value of active- and sluggish-type larvae (Wellington 1960, 1977). In the present study, growth during the 4 days of the trial was negatively correlated with quiescence. However, this did not translate into significant performance differences under laboratory conditions. In the field, an active caterpillar might be more likely to explore unmarked terrain and establish trails leading to new food sources, whereas sluggish individuals may remain restricted to following trails in previously explored areas. However, tent caterpillars are colonial, and an individual's fitness also depends on the functioning of the colony and, therefore, on the frequency distribution of types within the colony. Colonies with a high proportion of active larvae may feed more frequently, build larger trail networks, and more easily access undamaged foliage; however, they may also spend more time in travel and hence be more vulnerable to accident and predation. Although colonies with large numbers of sluggish individuals may feed less often, under highly dense conditions they are less likely to encounter other colonies in the same host tree and may be, consequently, less exposed to competition and to pathogens (Wellington 1960). There is, therefore, likely no such thing as an "all-pupose colony" (Wellington 1957) with an optimal ratio of active to sluggish larvae. Such environmentally dependent variation in selection pressures can act to maintain the diversity of behaviours within a population (Sih and Watters 2005).

Our results indicate that the intraspecific variability observed by Wellington (1957) in $M$. c. pluviale appears to extend to $M$. disstria. By designing a novel technique, widening the definition of active and sluggish types to include several mutually exclusive and observable activities, and extending the length of the trials, a deeper analysis of individual foraging types was possible. Future field research will now be able to focus on determining the frequency of sluggish and active types within colonies under different environmental contexts, as well as on examining how colony composition affects its functioning and performance in different environments. An understanding of intraspecific variation in outbreaking insect foraging behaviour may have important implications, both for our understanding of the social interactions and group dynamics in gregarious caterpillars and for the management of these important forest pests.

\section{Acknowledgements}

We thank Paul Albert and Grant Brown for their constructive comments and suggestions during the preparation of the manuscript. Many thanks also go to Nadia Colasurdo, David Gervais, Adila Khan, Audrey Dussutour, and Edward Varfalvy for their active input and help throughout the research. Two anonymous reviewers provided helpful comments. This work was supported by grants to E.D. from the Natural Sciences and Engineering Research Council of Canada and the Canadian Fund for Innovation. This study was conducted as a Concordia University Science College 490 undergraduate research project.

\section{References}

Addy, N.D. 1969. Rearing the forest tent caterpillar on an artificial diet. J. Econ. Entomol. 62: 270-271.

Bakker, K. 1961. An analysis of factors which determine success in 
competition for food among larvae of Drosophila melanogaster. Arch. Neerl. Zool. 14: 200-281.

Beshers, S.N., and Fewell, J.H. 2001. Models of division of labor in social insects. Annu. Rev. Entomol. 46: 413-440. doi:10. 1146/annurev.ento.46.1.413.

Colasurdo, N., and Despland, E. 2005. Social cues and following behaviour in the forest tent caterpillar. J. Insect Behav. 18: 7787. doi:10.1007/s10905-005-9348-6.

DeAngelis, D.L., and Mooij, W.M. 2005. Individual-based modeling of ecological and evolutionary processes. Annu. Rev. Ecol. Evol. Syst. 36: 147-168. doi:10.1146/annurev.ecolsys.36. 102003.152644.

de Bono, M. 2003. Molecular approaches to aggregation behavior and social attachment. J. Neurobiol. 54: 78-92. doi:10.1002/ neu.10162. PMID:12486699.

Despland, E. 2004. Locust transformation: from solitarious Dr. Jekyll to swarming Mr. Hyde. Biologist, 51: 18-22.

Despland, E., and Hamzeh, S. 2004. Ontogenetic changes in social behaviour in the forest tent caterpillar Malacosoma disstria. Behav. Ecol. Sociobiol. 56: 177-184. doi:10.1007/s00265-0040767-8.

Despland, E., and Le Huu, A. 2007. Pros and cons of group-living in the forest tent caterpillar: separating the roles of silk and of grouping. Entomol. Exp. Appl. 122: 181-189. doi:10.1111/j. 1570-7458.2006.00512.x.

Edgerly, J.S., and Fitzgerald, T.D. 1982. An investigation of behavioral variability within colonies of the eastern tent caterpillar Malacosoma americanum (Lepidoptera: Lasiocampidae). J. Kans. Entomol. Soc. 55: 145-155.

Everitt, B.S., Landau, S., and Leese, M. 2001. Cluster analysis. 4th ed. Oxford University Press, London.

Fitzgerald, T.D. 1995. The tent caterpillars. Cornell University, Ithaca, N.Y. pp. 64-80.

Fitzgerald, T.D. 2003. Role of trail pheromone in foraging and processionary behavior of pine processionary caterpillars Thaumetopoea pityocampa. J. Chem. Ecol. 29: 513-532. doi:10.1023/ A: 1022875102682.

Fitzgerald, T.D., and Webster, F.X. 1993. Identification and behavioral assays of the trail pheromone of the forest tent caterpillar Malacosoma disstria Hübner (Lepidoptera: Lasiocampidae). Can. J. Zool. 71: 1511-1515.

Greenblatt, J.A., and Witter, J.A. 1976. Behavioral studies on Malacosoma disstria (Lepidoptera: Lasiocampidae). Can. Entomol. 108: $1225-1228$.

Grisdale, D. 1985. Malacosoma disstria. In Handbook of insect rearing. Vol. 2. Edited by P. Singh and R.F. Moore. Elsevier, New York. pp. 369-379.

Iwao, S., and Wellington, W.G. 1970. The western tent caterpillar: qualitative differences and the action of natural enemies. Res. Popul. Ecol. 12: 81-99. doi:10.1007/BF02511084.

Lessells, C.M., and Boag, P.T. 1987. Unrepeatable repeatabilities: a common mistake. Auk, 104: 116-121.

Myers, J.H. 1978. A search for behavioural variation in first and last laid eggs of western tent caterpillar and an attempt to prevent a population decline. Can. J. Zool. 56: 2359-2363.

Noldus Information Technology Inc. 2003. Pocket Noldus Obser- ver. Version 2.0.19 [computer program]. Noldus Information Technology Inc., Leesburg, Va.

Ohnishi, S. 1979. Relationship between larval feeding behavior and viability in Drosophila melanogaster and Drosophila simulans. Behav. Genet. 9: 129-134. doi:10.1007/BF01074332. PMID:120743.

Robertson, F.W. 1963. The ecological genetics of growth in Drosophila. Genet. Res. 4: 74-92.

Robison, D.J. 1993. The feeding ecology of the forest tent caterpillar, Malacosoma disstria Hübner, among hybird poplar clones, Populus spp. Ph.D. dissertation, University of Wisconsin, Madison.

Schoonhoven, L.M. 1987. What makes a caterpillar eat? The sensory code underlying feeding behaviour. In Perspectives in chemoreception and behaviour. Edited by R.F. Chapman, E.A. Bernays, and J.G. Stoffolano. Springer-Verlag, New York. pp. 69-97.

Sih, A., and Watters, J.V. 2005. The mix matters: behavioural types and group dynamics in water striders. Behaviour, 142: 1417-1431. doi:10.1163/156853905774539454.

Sih, A., Bell, A.M., and Johnson, J.C. 2004. Behavioral syndromes: an ecological and evolutionary overview. Trends Ecol. Evol. 19: 372-378. doi:10.1016/j.tree.2004.04.009. PMID:16701288.

Sokal, R.R., and Rohlf, J.F. 1981. Biometry: the principles and practice of statistics in biological research. W.H. Freeman and Co., San Francisco.

Sokolowski, M.B. 1985. Genetic aspects to differences in foraging behavior. Behav. Brain Sci. 8: 348-349.

Sokolowski, M.B. 2001. Drosophila: genetics meets behaviour. Nat. Rev. Genet. 2: 879-890. doi:10.1038/35098592. PMID:11715043.

SPSS Inc. 2003. SPSS ${ }^{\circledR}$. Version 12.0.1 [computer program]. SPSS Inc., Chicago.

Underwood, D.L.A., and Shapiro, A.M. 1999. Evidence for division of labor in the social caterpillar Eucheira socialis (Lepidoptera: Pieridae). Behav. Ecol. Sociobiol. 46: 228-236. doi:10. 1007/s002650050614.

van Oers, K., de Jong, G., van Noordwijk, A.J., Kampenaers, B., and Drent, P.J. 2005. Contributions of genetics to the study of animal personalities: a review of case studies. Behaviour, 142: 1185-1206. doi:10.1163/156853905774539364.

Weinstein, P., and Maelzer, D.A. 1997. Leadership behaviour in sawfly larvae Perga dorsalis (Hymenoptera: Pergidae). Oikos, 79: 450-455. doi:10.2307/3546887.

Wellington, W.G. 1957. Individual differences as a factor in population dynamics: the development of a problem. Can. J. Zool. 35: 293-323.

Wellington, W.G. 1960. Qualitative changes in natural populations during changes in abundance. Can. J. Zool. 38: 289-314.

Wellington, W.G. 1965. Some maternal influences on progeny quality in the western tent caterpillar, Malacosoma pluviale (Dyar). Can. Entomol. 97: 1-14.

Wellington, W.G. 1977. Returning the insect to insect ecology: some consequences for pest management. Environ. Entomol. 6: $1-8$.

Wilson, D.S., Coleman, K., Clarke, A.B., and Biederman, L. 1994. Shyness and boldness in humans and other animals. Trends Ecol. Evol. 9: 442-446. doi:10.1016/0169-5347(94)90134-1. 